\title{
The Study in Vitamin D Concentration in the Blood for Infants with High Level of Alkaline Phosphatase
}

\author{
Ji Sung Kim ${ }^{1}$, Jae Yong Choi ${ }^{1}$, Kyun Woo Lee ${ }^{1}$, Ick Jin Song ${ }^{1}$, Cheol Am Kim ${ }^{1}$, \\ Byeong Hee Son ${ }^{1}$, Jung Hyun Lee
}

${ }^{1}$ Department of Pediatrics, Dae-Dong Hospital, ${ }^{2}$ Department of Pediatrics, College of Medicine, Kosin University, Busan, Korea

\section{혈중 고 알칼리인산분해효소치를 보인 영아에서 혈중 비타민 D 농도에 대한 연구}

\author{
김지성 ${ }^{1}$ 최재용 ${ }^{1} \cdot$ 이균우 ${ }^{1} \cdot$ 송익진 $^{1} \cdot$ 김철암 $^{1} \cdot$ 손병희 $^{1} \cdot$ 이정현 $^{2}$ \\ ${ }^{1}$ 대동병원 소아청소년과, ${ }^{2}$ 고신대학교 의과대학 소아청소년과학교실
}

Objectives: Nowadays most infants on exclusively breast feeding have vitamin D deficiency due to the increase of breast feeding. However, domestic research lacks appropriate materials. Therefore, we researched practical clinical aspects of vitamin D deficiency related to breast milk feeding for infants who have a high amount of alkaline phosphatase (> $500 \mathrm{IU} / \mathrm{L}$ ).

Methods: The subjects of the study were 31 infants with high alkaline phosphatase level. We tested with 25-hydroxycholecalciferol $\left(25-\mathrm{OHD}_{3}\right)$, parathyroid hormone, calcium, ionized calcium, phosphorus in their blood and with a wrist x-ray. Then, we divided them into two groups of breast feeding and formula feeding and compared the results.

Results: Eighteen infants (58\%) out of 31 infants that have high alkaline phosphatase were vitamin D insufficiency or deficiency, and $16(100 \%)$ breast feeding infants of them showed vitamin D deficiency or insufficiency. However, only $2(13 \%)$ of 15 formula feeding infants were at insufficiency. There was a correlation between alkaline phosphatase and $25-\mathrm{OHD}_{3}$ concentration in multiple regression analysis, but no correlation in other variables was found in group of breast milk feeding infants. There was neither correlation between vitamin D concentration and alkaline phosphatase nor other correlated variables in the group of formula milk feeding infants.

Conclusions: In this study, there was a high probability of vitamin D deficiency in the breast feeding infants with a high alkaline phosphatase level. Therefore, it is considered to be worth utilizing alkaline phosphatase as a screening test for vitamin D deficiency or rickets for breast feeding infants.

Key Words: Alkaline phosphatase, Vitamin D deficiency, Breast feeding

비타민 $\mathrm{D}$ 는 근 골격계, 성장과 발육, 신경계, 내분비계 및 면역기능 발달에 관여하며 골격계에서 칼슘과 인의 방출 및 장관에서 칼슘과 인의 흡수를 촉진하여 뼈의 무기 질화 및 근 골격계와 대사 작용에 관여하는 호르몬으로 부족시 구루병 및 성장 발달의 지연, 각종 암과 당뇨병 발병 가능성이 있으며 호흡기 질환, 특히 천명음을 동반한
천식과 관련이 있다는 보고가 있다. ${ }^{1,2}$

인체 내 비타민 $\mathrm{D}$ 는 햇빛을 통해 피부에서 합성되며 음식 섭취를 통해 만들어지거나 흡수가 된다. 비록 개개인 의 차이가 있지만 햇빛을 통해 80-90\% 형성되고 음식을 통한 흡수는 상대적으로 적은 편이다. ${ }^{3}$ 대기오염으로 인 한 일조량의 감소 ${ }^{4}$ 와 과거와 다른 아파트 식 주거 조건,
Corresponding Author: Kyun Woo Lee, Department of Pediatrics, Dae-Dong Hospital, 187 Chungyel-daero, Dongrae-gu, Busan, 607-711, Korea

TEL: 051) 550-9257 FAX: 051) 553-7575 E-mail: pedrics@ hanmail.net
Received: November 29, 2011

Revised: February 16, 2012

Accepted: February 23, 2012 
광범위한 자외선 차단제의 사용, 완전 모유수유의 장려 등 여러 가지 인자에 의해 비타민 $\mathrm{D}$ 의 인체 내 합성과 흡수에 관련된 여러 조건들이 변화하고 있는 상태이 다. ${ }^{5,6,7}$

최근 아시아 국가들의 비타민 D 결핍에 대한 연구를 살펴보면 중국 영아와 청소년에서 비타민 D 결핍은 청소 년에서 5-15\%, 영아는 40\%에 달했으며, 8 , Faser의 연구 에 의하면 몽고의 1 세 이하 영아에서 120 명 중 $24 \%$ 가 비타민 D 결핍이었다. ${ }^{10}$ 또한 여러 선진국에서도 비타민 $\mathrm{D}$ 결핍이 흔히 일어나고 있는 것으로 알려지고 있으며 이로 인한 구루병이 다시 발생하고 있다. ${ }^{11,12}$ 하지만 아직 까지 국내에서 소아연령에 대한 비타민 D 상태에 관한 연구는 많지 않은 상태이고 비타민 $\mathrm{D}$ 부족이나 결핍에 대한 관심도 상당히 낮은 편이며 특히 돌 전 아동에 대해서 는 더더욱 그러하다. 몇몇의 국내 연구는 모유 수유아를 대상으로 한 연구가 대부분이며 분유 수유아나 다른 변수 와 관련된 비타민 D 결핍 관련 연구는 드문 편이다. ${ }^{13,14}$

소아청소년과 의사들은 여러 가지 질환으로 아이들을 입원 치료할 기회를 가진다. 이 때 정상 알칼리인산분해효 소(Alkaline phosphatase, ALP)치인 145-420 IU/L 이 상으로 높은 경우를 흔히 볼 수 있다. 이에 본 연구에서는 비타민 D 결핍과 관련하여 선별검사로 이용하자는 주장 이 있는 알칼리인산분해효소 치가 높은 입원 환아 $>500$ $\mathrm{IU} / \mathrm{L})$ 를 대상으로 모유 수유아와 분유 수유아로 나누어 비타민 D 혈중 농도에 어떠한 차이가 있는지를 알고자 이 연구를 시행하였다. ${ }^{15,16}$

\section{연구대상 및 방법}

\section{1. 연구대상}

2011년 1월부터 2011년 8월까지 부산 대동병원 소아청 소년과에서 폐렴, 기관지염, 장염 등의 질환으로 입원했 던 환아 중 알칼리인산분해효소치가 증가한 환아들에 대 해 보호자의 동의하에 33 명을 검사하였고 그 중 모유와 분유를 함께하였던 혼합 수유아 2 명은 제외하고 31 명을 대상으로 하여 모유 수유군 16 명과 분유 수유군 15 명으로
나누어 검사 결과에 대한 분석을 시행하였다.

\section{2. 방법}

대동병원 소아청소년과에 폐렴, 기관지염, 장염 등 급성 감염성 질환으로 입원한 아동 중 혈액 내 알칼리인산분해 효소치가 높은 환아 31 예를 대상으로 조사를 하였으며 이들 환아의 혈액검사를 통해 혈중의 칼슘 $(\mathrm{Ca})$ 과 이온화 칼슘 $\left(\mathrm{Ca}^{2+}\right)$, 인(P), 비타민 $\mathrm{D}_{3}$ (25-hydroxycholecalciferol, 25- $\mathrm{OHD}_{3}$ ), 그리고 부갑상샘 호르몬(intact-parathyroid hormone, PTH) 등을 측정하였다. 각각의 검사 방법은 칼슘은 Arsenazo III, 이온화 칼슘은 ion selective electrolyte (ISE), 인은 비색법, 비타민 $\mathrm{D}_{3}$ 와 부갑상샘 호르몬은 chemiluminescence immunoassay (CLIA)를 사용하였다. 비타민 D 부족(insufficiency)은 American Academy of Pediatrics (AAP)에서 최근에 설정한 기준 인 혈액 내 $25-\mathrm{OHD}_{3}$ 의 농도가 $30 \mathrm{ng} / \mathrm{mL}$ 미만인 경우로 정의하였고, 비타민 D 결핍(deficiency)은 $20 \mathrm{ng} / \mathrm{mL}$ 미 만으로 정의 하였다. ${ }^{6}$ 대상 환아의 경우 보호자 면담을 통해 모유 수유의 여부와 기간, 현재 식이 형태, 이유식 여부, 일조시간, 주거 형태를 조사하였다(Table 1).

\section{3. 통계}

통계적 방법은 SPSS (version 11.5; SPSS Inc, Chicago, IL, U.S.A.)를 이용하였으며 $P<0.05$ 일 때 유의 한 것으로 판정하였다. 모유 수유군과 분유 수유군 사이의 각각의 독립변수 비교는 $\mathrm{T}$ 검정(Independent Sample $\mathrm{T}$-test)을 사용하였으며, 알칼리인산분해효소와 다른 독 립변수와의 상관관계는 단변량분석(univariate analysis) 과 다중회귀분석(multiple logistic regression analysis) 을 실시하였다.

\section{결 과}

\section{1. 대상 환아들의 특성}

대상 환아 31 명의 평균연령은 $9.5 \pm 2.3$ 개월이었고 남 아가 23 명 여아가 8 명이었다. 대상 환아들이 입원한 이유 
Table. 1 Clinical profile of the cases of high level of alkaline phosphatase

\begin{tabular}{|c|c|c|c|c|c|c|c|}
\hline & $\begin{array}{l}\text { Age } \\
\text { (Mo) }\end{array}$ & Gender & Feeding & Weaning Food & $\begin{array}{c}\text { Type of } \\
\text { Residence } \\
\end{array}$ & $\begin{array}{c}\text { Time of exposure to } \\
\text { sunlight }\end{array}$ & $\begin{array}{c}\text { Clinical } \\
\text { menifestation }\end{array}$ \\
\hline 1 & 8 & M & $\mathrm{BMF}$ & groin, fruit, meat, seafood & apartment & beolw 1 hour & AGE \\
\hline 2 & 11 & $\mathrm{~F}$ & $\mathrm{BMF}$ & groin, fruit, meat, seafood & house & beolw 1 hour & bronchitis \\
\hline 3 & 8 & M & $\mathrm{BMF}$ & instant weaning food & apartment & beolw 1 hour & pneumonia \\
\hline 4 & 6 & $\mathrm{~F}$ & $\mathrm{BMF}$ & groin, fruit & apartment & beolw 1 hour & $\mathrm{APT}$ \\
\hline 5 & 8 & M & $\mathrm{BMF}$ & groin, fruit, meat & house & beolw 1 hour & APT \\
\hline 6 & 8 & M & $\mathrm{BMF}$ & groin, fruit & house & beolw 1 hour & bronchitis \\
\hline 7 & 13 & $\mathrm{~F}$ & $\mathrm{BMF}$ & groin, fruit, meat, seafood & apartment & about 2-4 hours & bronchitis \\
\hline 8 & 8 & M & $\mathrm{BMF}$ & groin, fruit, seafood & apartment & beolw 1 hour & pneumonia \\
\hline 9 & 9 & M & $\mathrm{BMF}$ & instant weaning food & house & beolw 1 hour & APT \\
\hline 10 & 9 & M & $\mathrm{BMF}$ & instant weaning food & apartment & about $1-2$ hours & pneumonia \\
\hline 11 & 6 & $\mathrm{~F}$ & $\mathrm{BMF}$ & groin, fruit, meat & house & beolw 1 hour & pneumonia \\
\hline 12 & 12 & M & BMF & groin, fruit, meat, seafood & house & beolw 1 hour & bronchitis \\
\hline 13 & 11 & $\mathrm{~F}$ & $\mathrm{BMF}$ & groin, fruit, meat, seafood & apartment & beolw 1 hour & bronchitis \\
\hline 14 & 7 & M & $\mathrm{BMF}$ & groin, fruit, seafood & house & beolw 1 hour & UTI \\
\hline 15 & 6 & M & $\mathrm{BMF}$ & groin, fruit, meat & house & beolw 1 hour & pneumonia \\
\hline 16 & 11 & M & $\mathrm{BMF}$ & groin, fruit, meat, seafood & apartment & beolw 1 hour & AGE \\
\hline 17 & 12 & M & FMF & groin, fruit, meat, seafood & apartment & about $1-2$ hours & APT \\
\hline 18 & 12 & M & FMF & groin, fruit, meat, seafood & apartment & beolw 1 hour & APT \\
\hline 19 & 12 & M & FMF & groin, fruit, meat, seafood & house & beolw 1 hour & bronchitis \\
\hline 20 & 12 & $\mathrm{~F}$ & FMF & groin, fruit, meat, seafood & apartment & beolw 1 hour & APT \\
\hline 21 & 10 & M & FMF & groin, fruit, meat, seafood & house & beolw 1 hour & APT \\
\hline 22 & 11 & M & FMF & groin, fruit, meat, seafood & house & beolw 1 hour & bronchitis \\
\hline 23 & 8 & $\mathrm{~F}$ & FMF & instant weaning food & apartment & beolw 1 hour & pneumonia \\
\hline 24 & 10 & M & FMF & groin, fruit, meat, seafood & apartment & beolw 1 hour & APT \\
\hline 25 & 7 & M & FMF & groin, fruit, meat, seafood & apartment & beolw 1 hour & bronchitis \\
\hline 26 & 12 & M & FMF & groin, fruit, meat, seafood & house & beolw 1 hour & Kawasaki's Dz \\
\hline 27 & 11 & M & FMF & groin, fruit, meat, seafood & apartment & beolw 1 hour & $\mathrm{H}-\mathrm{F}-\mathrm{M} \mathrm{Dz}$ \\
\hline 28 & 11 & M & FMF & instant weaning food & house & beolw 1 hour & AGE \\
\hline 29 & 6 & M & FMF & instant weaning food & apartment & beolw 1 hour & pneumonia \\
\hline 30 & 12 & M & FMF & groin, fruit, meat, seafood & house & beolw 1 hour & bronchitis \\
\hline 31 & 6 & $\mathrm{~F}$ & FMF & groin & apartment & beolw 1 hour & pneumonia \\
\hline
\end{tabular}

Mo: Month, M: Male, F: Female, BMF: Breast milk feeding, FMF: Formula milk feeding, AGE: Acute gastroenteritis, APT: Acute pharyngotosilits, UTI: Urinary track infection, Dz: Disease, H-F-M: Hand foot mouth.

는 기관지염 9명, 폐렴 8 명, 인후염 8 명, 장염 3 명 그리고 기타 질병(수족구병, 가와사키병, 요로감염) 3 명의 순이 었다. 전체 환아 중 모유 수유아는 16명(52\%), 분유 수유 아는 15 명 $48 \%)$ 이었다. 모유 수유와 분유 수유를 함께 시행하였던 2 명은 이 연구에서 제외하였다. 모유 수유아 16 명의 평균 연령은 $8.9 \pm 2.2$ 개월이었고 남녀 비는 $2.2: 1$ 이었다. 분유 수유아 15 명의 평균 연령은 $10.1 \pm 2.3$ 개월 이었고 남녀 비는 4:1이었다(Table 1).

\section{2. 검사 결과}

전체 환아 31 명의 $25-\mathrm{OHD}_{3}$ 평균치는 $26.5 \pm 14 \mathrm{ng} / \mathrm{mL}$ 로 부족의 범위에 해당하였고 알칼리인산분해효소의 평 균치는 $809.9 \pm 357.5 \mathrm{IU} / \mathrm{L}(145-420 \mathrm{IU} / \mathrm{L})$ 였다. 전체 환아 31명 중 비타민 D 부족 환아는 4명(13\%)이었으며 비타민 D 결핍 환아는 14 명(45\%)이었다. 비타민 $\mathrm{D}$ 의 부 족이나 결핍이 있었던 환아 18 명 중 모유 수유아는 16 명 
(88.9\%), 분유 수유아는 2명(11.1\%)이었다.

모유 수유군의 $25-\mathrm{OHD}_{3}$ 의 평균치는 $15.0 \pm 6.3$ $\mathrm{ng} / \mathrm{mL}$ 으로 결핍의 범위에 해당하였고 비타민 $\mathrm{D}$ 결핍 환아는 14 명 (87.5\%), 비타민 D 부족 환아는 2명(12.5\%) 이었다. 대상 영아 중 체내 $25-\mathrm{OHD}_{3}$ 이 $4 \mathrm{ng} / \mathrm{mL}$ 이하로 심각한 비타민 $\mathrm{D}$ 결핍 소견을 보인 환아는 3 명이었다. 분유 수유군의 $25-\mathrm{OHD}_{3}$ 평균치는 $36.5 \pm 5.7 \mathrm{ng} / \mathrm{mL}$ 였 으며, 비타민 D 부족 환아는 2명(13.3\%), 비타민 D 결핍 환아는 없었다.

모유 수유군과 분유 수유군 사이에서 각각의 변수 비교 는 $\mathrm{T}$ 검정을 이용하였으며 알칼리인산분해효소 $(P=$ $0.006), 25-\mathrm{OHD}_{3}(P<0.001)$, 그리고 부갑상샘 호르몬
$(P=0.021)$ 등은 두 군 간에 유의한 차이를 보였다. 그러나 연령, 성별, 칼슘, 이온화 칼슘, 인 등의 변수들은 두 군 간에 유의한 차이를 보이지 않았다(Table 2).

비타민 D 혈중 농도와 다른 독립변수와의 통계학적 상관관계를 분석한 결과, 모유 수유군에서 비타민 D 혈중 농도는 $\mathrm{T}$ 검정을 이용한 단변량분석(univariate analysis) 에서 알칼리인산분해효소와 부갑상샘 호르몬에서 상관 관계를 보였으나 다중회귀분석(multiple logistic regression analysis)에서 알칼리인산분해효소 치만이 유의한 상관관계를 보였고 $(P=0.032)$ 다른 독립 변수들과는 상 관관계를 보이지 않았다(Table 3, Table 4, Fig. 1). 그러 나 분유 수유군에서는 비타민 D 혈중농도는 단변량 분석

Table 2. Comparison of clinical profile between breast feeding infants and formula milk feeding infants $(\mathrm{n}=31)$

\begin{tabular}{lccc}
\hline & $\begin{array}{c}\text { Breast milk feeding } \\
(\mathrm{n}=16)\end{array}$ & $\begin{array}{c}\text { Formula milk feeding } \\
(\mathrm{n}=15)\end{array}$ & $P$ value \\
\hline Age $(\mathrm{Mo})$ & $8.9 \pm 2.2^{\dagger}$ & $10.1 \pm 2.3^{\dagger}$ & 0.172 \\
$\mathrm{Sex}(\mathrm{M}: \mathrm{F})$ & $11: 5$ & $12: 3$ & 0.491 \\
$\mathrm{Ca}^{2+}(\mathrm{mmol} / \mathrm{L})$ & $1.3 \pm 0.1^{\dagger}$ & $1.3 \pm 0.1^{\dagger}$ & 0.753 \\
$\mathrm{Ca}(\mathrm{mg} / \mathrm{dL})$ & $10.3 \pm 0.3^{\dagger}$ & $10.1 \pm 0.5^{\dagger}$ & 0.292 \\
$\mathrm{P}(\mathrm{mg} / \mathrm{dL})$ & $4.6 \pm 0.7^{\dagger}$ & $4.9 \pm 0.7^{\dagger}$ & 0.176 \\
$\mathrm{ALP}(\mathrm{U} / \mathrm{L})$ & $998.7 \pm 420.2^{\dagger}$ & $621.1 \pm 85.2^{\dagger}$ & 0.006 \\
$\mathrm{PTH}(\mathrm{pg} / \mathrm{mL})$ & $43.8 \pm 2.4^{\dagger}$ & $15.1 \pm 4.9^{\dagger}$ & 0.021 \\
$25-\mathrm{OHD}(\mathrm{ng} / \mathrm{mL})$ & $15.0 \pm 6.3^{\dagger}$ & $36.5 \pm 5.7^{\dagger}$ & $P<0.001$ \\
\hline
\end{tabular}

${ }^{\dagger}$ Data are expressed as mean \pm standard deviation (range).

$P<0.05$ is significant.

n: numbers, Mo: Month, M: Male, F: Female, $\mathrm{Ca}^{2+}$ : ionized calcium, Ca: Calcium, P: Phosphorus, ALP: Alkaline phosphatase, PTH: intact parathyroid hormone, 25- $\mathrm{HDD}_{3}$ : 25-hydroxycholecalciferol

Table 3. Univariate analysis between 25-hydroxycholecalciferol and the variables

\begin{tabular}{|c|c|c|c|c|}
\hline \multirow{2}{*}{ Variables } & \multicolumn{2}{|c|}{ Breast milk feeding } & \multicolumn{2}{|c|}{ Formula milk feeding } \\
\hline & Coefficient & $P$ value & Coefficient & $P$ value \\
\hline Age (Mo) & 0.425 & 0.101 & -0.161 & 0.566 \\
\hline Sex & 0.220 & 0.413 & 0.347 & 0.205 \\
\hline $\mathrm{Ca}^{2+}$ & 0.305 & 0.251 & -0.275 & 0.321 \\
\hline $\mathrm{Ca}$ & 0.451 & 0.079 & -0.309 & 0.262 \\
\hline $\mathrm{P}$ & 0.388 & 0.137 & 0.124 & 0.661 \\
\hline PTH & -0.611 & 0.012 & -0.21 & 0.940 \\
\hline ALP & -0.634 & 0.008 & -0.125 & 0.657 \\
\hline
\end{tabular}

Spearman correlation, Sex (male $=1$, female $=2), P<0.05$ is significant.

Mo: Month, $\mathrm{Ca}^{2+}$ : ionized calcium, Ca: CALCIUm, P: Phosphorus, PTH: intact-parathyroid hormone, ALP: Alkaline phosphatase 
Table 4. Predictors for 25-hydroxycholecalciferol in multiple regression analysis in breast milk feeding group

\begin{tabular}{lcc}
\hline \multirow{2}{*}{ Variables } & \multicolumn{2}{c}{ Breast milk feeding } \\
\cline { 2 - 3 } Constant & Regression coefficient & $P$ value \\
Age (Mo) & 21.721 & 0.01 \\
Sex & 0.335 & 0.147 \\
$\mathrm{Ca}^{2+}$ & -0.94 & 0.717 \\
$\mathrm{Ca}$ & 0.183 & 0.464 \\
P & 0.302 & 0.215 \\
PTH & -0.352 & 0.315 \\
ALP & -0.278 & 0.357 \\
\hline
\end{tabular}

Multiple regression analysis (stepwise method), Sex (male=1, female=2), $P<0.05$ is significant.

Mo: Month, $\mathrm{Ca}^{2+}$ : ionized calcium, Ca: Calcium, P: Phosphorus, PTH: intact-parathyroid hormone, ALP: Alkaline phosphatase

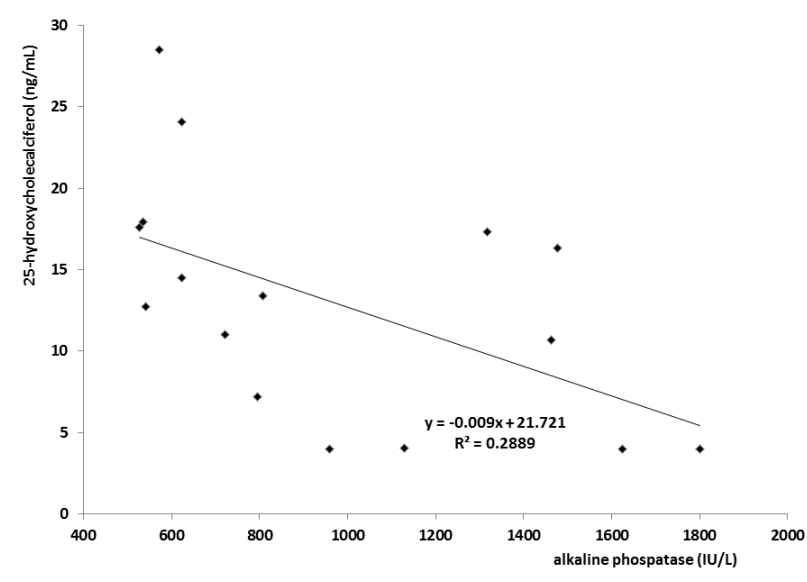

Fig. 1. Association between alkaline phosphatase and 25hydroxycholecalciferol in breast milk feeding infants

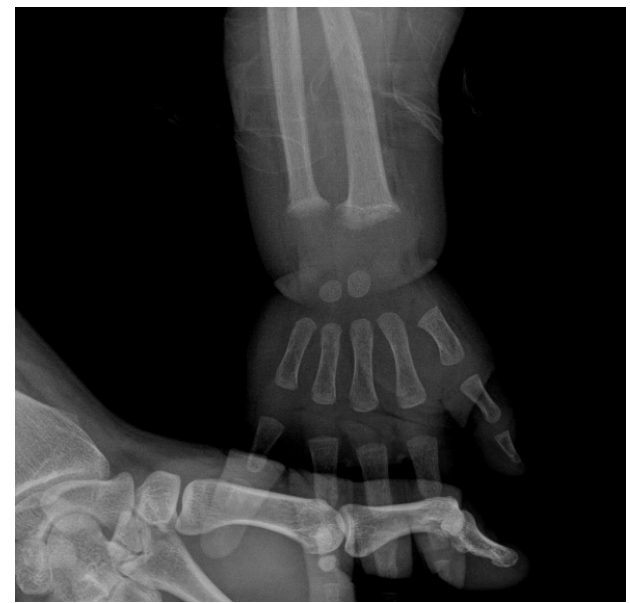

Fig. 2. Radiograph of wrist in a patient of asymptomatic rickets. there are cupping, spraying and fraying in ulna and radius. It is grade 2 , moderate.
에서 어떠한 독립변수와도 유의한 상관관계를 보이지 않 았다(Table 3).

수부 방사선 검사에서 손목 골간단의 중앙부가 컵 모양 으로 들어가거나 골간단의 경계가 불분명해지는 등의 구 루병 방사선 소견을 보인 경우는 4명에서 발견되었다 (Fig. 2).

\section{고 찰}

과거에는 흔히 볼 수 있었던 비타민 $\mathrm{D}$ 결핍성 질환이 감소했다가 1990년 후반부터 증가되고 있는 추세이다. ${ }^{1}$ 예전에는 제한된 일조량을 가지거나 영양 결핍이 있는 저개발국에서 주로 발생하였으나 최근에는 일조량이 풍 부한 국가나 선진국에서도 보고되고 있다. ${ }^{17,18}$ 이러한 이 유로는 일조량이나 주거환경의 변화, 자외선 차단제의 사용, 그리고 식이조절이나 모유 수유의 장려 등이 알려져 있다. ${ }^{5,6,7}$

비타민 $\mathrm{D}$ 는 자외선과 음식을 통해 체내에서 합성되거 나 흡수되게 되는데 비타민 $\mathrm{D}$ 는 등 푸른 생선과 생선 기름, 계란, 간, 우유와 유제품 등에 주로 존재한다. ${ }^{19,20}$ 그러나 음식을 통해서는 비타민 D 요구량의 $10 \%$ 이하 정도만 보충할 수 있다. ${ }^{6}$ 따라서 알레르기로 인한 제한 식이, 예를 들면 계란 알레르기 등으로 인해 제한 식이를 할 경우 비타민 D 결핍이 발생할 수 있다는 연구결과도 
있다. ${ }^{17,21}$

비타민 D 결핍의 경우 일반적으로 $25-\mathrm{OHD}_{3}$ 을 측정하 고 $1,25-\mathrm{OH}_{2} \mathrm{D}_{3}$ (1,25-dihydroxyvitamin $\left.\mathrm{D}\right)$ 는 측정하지 않는데 이는 비타민 $\mathrm{D}$ 결핍이 있을 경우 보통 serum ionized calcium이 감소하며 이로 인해 부갑상샘의 calcium channel이 활성화 되고 이로 인해 부갑상샘 호르 몬의 분비가 증가할 수 있으며 $1,25-\mathrm{OH}_{2} \mathrm{D}_{3}$ 의 경우 부갑 상샘 항진증이 있을 때 신장에서 $1,25-\mathrm{OH}_{2} \mathrm{D}_{3}$ 의 생산을 증가시켜 실제 낮은 상태인데도 정상이거나 높은 결과로 나올 수 있기 때문이다. ${ }^{1}$

자외선에 노출되면 피부에 있는 7-hydrocholesterol 로부터 대사 과정을 거쳐 체내에 필요한 비타민 $\mathrm{D}$ 가 생성 되게 된다. ${ }^{1}$ 자외선을 통한 비타민 $\mathrm{D}$ 의 생성량은 백인의 경우 여름에 10-15분 노출되었을 때 10,000-20,000 IU를 생성하며 피부가 검은 경우 백인과 같은 양의 비타민 $\mathrm{D}$ 를 생성하기 위해서는 5-10배의 노출을 필요로 한다. ${ }^{5,22}$ 최 근 광범위한 자외선 차단제 사용과 실내 생활의 시간이 길어짐에 따라 비타민 D 합성이 줄게 되었다. 실제 1989년 Air Quality Act에 따르면 미국인의 경우 시간의 $93 \%$ 를 실내에서 보낸다고 보고되었다. ${ }^{5}$ 본 연구에 포함된 영아 의 부모들은 비타민 D 합성을 위해 실외에서 자외선 노출 의 필요성을 느끼고 있는 경우는 거의 없었다. 따라서 모유 수유아와 같은 고 위험군에서의 경우 적절한 야외 활동의 장려가 필요하다고 생각된다.

또한 최근 모유 수유의 중요성이 강조되면서 국내의 모유 수유율은 6개월 미만의 완전 모유 수유율이 2000년 9.5\%, 2003년 29.5\%, 2006년 26.8\%, 2009년 36.2\%로 지 속적으로 증가하고 있는 추세 ${ }^{23}$ 이지만 모유에서의 비타민 $\mathrm{D}$ 함유량은 33-68 IU/L $\mathrm{L}^{24}$ 로 $400 \mathrm{IU} / \mathrm{L}$ 이 들어있는 분유에 비해 절대량이 적고, 최근 소아 권장량인 $400 \mathrm{IU} / d a y$ 에 크게 못 미치는 실정이다. ${ }^{6,25}$ 본 연구에서도 비타민 D 부족이나 결핍 환자의 $89 \%$ 가 모유 수유아에 해당하였고 $25-\mathrm{OHD}_{3}$ 의 혈중 농도도 모유 수유아 군에서 분유 수유군 에 비하여 현저하게 낮았다. 따라서 모유 수유의 증가와 비타민 D 결핍이 밀접한 관련이 있다고 생각된다.

이러한 위험들로 인해 2003년 AAP에서는 구루병과
비타민 D 결핍 예방을 위해 모유 수유아에서 생후 2개월 안에 비타민 D $200 \mathrm{IU}$ 의 공급을 권고 했으나 ${ }^{5,25}$ 연구 결과 비타민 D 결핍을 예방하기에 충분하지 않다고 결론 짓고 체내의 $25-\mathrm{OHD}_{3}$ 을 적어도 $20 \mathrm{ng} / \mathrm{mL}$ 이상 유지하 기 위해서 2008년 새로운 권고안을 발표하였다. 이 권고 안에 의하면 모유수유아의 경우 태어나서 수일 이내 비타 민 D $400 \mathrm{IU}$ 의 복용을 시작하고, 분유수유아의 경우 하루 에 $1,000 \mathrm{~mL}$ 이하의 비타민 $\mathrm{D}$ 강화 분유를 먹는다면 400 $\mathrm{IU}$ 의 비타민 D 복용을 권고했다. 사춘기의 경우 하루에 $400 \mathrm{IU}$ 이하에 해당하는 비타민 D 강화우유나 음식을 먹는 경우 $400 \mathrm{IU}$ 를 복용하고 체내 비타민 D 양이 최저 $20 \mathrm{ng} / \mathrm{mL}$ 이상을 유지하도록 권고하고 있다. $25-\mathrm{OHD}_{3}$ 의 경우 비정상인 경우 3 개월마다 추적 관찰하고 부갑상 샘 호르몬, bone mineral은 6 개월마다 정상이 될 때까지 추적관찰을 권고하고 있다. ${ }^{6}$

알칼리인산분해효소는 뼈, 간, 대장, 신장의 근위 곡세 관, 태반 등에서 주로 나타난다. 전체적인 알칼리인산분 해효소는 나이와 뼈의 분포에 따라 다양하게 나타나며 주로 영아나 사춘기 시에 급속한 성장이 있을 때 증가하게 된다. 또한 부갑상샘 항진증, 구루병, 골연화증, Paget 병 과 같은 골격 질환에서 일차적인 생화학적 지표로 사용된 다. 또한 감염성 질환에서 증가하며 이는 benign hyperalkaline phosphatasemia의 원인으로 알려져 있다. 알칼 리인산분해효소는 나이에 따라 많은 차이를 보이는데 생 후 첫 6 개월 이내에 최고치에 달하고 이후 서서히 감소하 다 9세 이후 다시 증가하는 경향을 보이며, 여성에서는 12세 이후 남성에서는 14세 이후부터 감소하여서 남성의 경우 $16-18$ 세경에 성인 농도에 도달하게 된다. ${ }^{26,27}$

본 연구결과에서 보면 모유 수유군에서 여러 가지 독립 변수 중 알칼리인산분해효소만이 비타민 D 혈중농도와 유의한 상관관계를 보였고 실제로 알칼리인산분해효소 치가 높은 모유 수유군 모두에서 비타민 $\mathrm{D}$ 의 부족이나 결핍 상태를 보였다. 그러나 분유 수유군에서는 비타민 $\mathrm{D}$ 혈중농도와 알칼리인산분해효소 사이에는 상관관계를 발견하지 못했고 비타민 D 혈중농도와 유의한 상관관계 를 보인 다른 독립변수도 없었다. 분유 수유군에서의 알칼 
리인산분해효소의 상승은 급속 성장기 또는 감염성 질환, 가족성 질환으로 인한 benign hyperalkaline phosphatasemia 등의 원인에 의한 것으로 생각해야 할 것 같다. 모유 수유군에서도 가족성, 감염성 질환으로 인한 알칼리 인산분해효소치의 증가 또한 영향을 주었다고 생각된다. 하지만 통계학적 상관관계를 고려해 볼 때 적어도 모유 수유아에서 알칼리인산분해효소는 비타민 D 혈중농도의 상태에 대한 선별검사로 어느 정도의 효용성을 지녔다고 판단된다. 따라서 고 위험군인 모유 수유아에서 알칼리인 산분해효소치가 높은 경우 $25-\mathrm{OHD}_{3}$, 부갑상샘 호르몬, 칼슘, 인, 그리고 방사선 등의 검사를 실시하여 비타민 $\mathrm{D}$ 결핍과 구루병에 대한 적극적인 진단이 이루어져야 할 것으로 생각된다. 또한 선별검사로의 정확성을 판단하 기 위해서는 감염성 질환을 배제한 상태에서 체내 알칼리 인산분해효소를 측정하고 이와 비타민 D 결핍의 상관관 계를 연구하는 것이 도움이 되리라 생각된다.

연구 결과에서 비타민 D 결핍 아동의 빈도가 높게 나왔 고 따라서 비타민 D 결핍에 대한 전국적인 역학조사가 필요하다고 생각이 되며 이를 통해 비타민 D 결핍의 빈도 를 구체적으로 파악하고 비타민 D 결핍이나 구루병에 대한 체계적 치료가 이루어져야겠다.

이번 연구에서 비타민 $\mathrm{D}$ 부족이나 결핍으로 진단된 아동에게 하루 400-2,000 IU 정도에 해당하는 비타민 $\mathrm{D}$ 보충제를 처방하였다. 현재 우리나라에서 아동들에게 사용 가능한 비타민 $\mathrm{D}$ 보충제는 올비틸, 써니 $\mathrm{D}$, 그리고 페디오 키디 정도가 시판되고 있다. 이번 연구에서는 비타 민 $\mathrm{D}$ 보충제 투여 후 비타민 $\mathrm{D}$ 의 혈중 농도 변화나 방사선 학적 호전에 관한 추적관찰에 대한 분석은 이루어지지 못했고 이에 대한 연구가 향후 필요할 것으로 생각된다.

\section{참고문헌}

1. Holick MF. Resurrection of Vitamin D deficiency and rickets. J Clin Invest 2006;116:2062-72.

2. Prentice A, Goldberg GR, Schoenmakers I. Vitamin D across the lifecycle: physiology and biomarkers. Am J Clin Nutr 2008;88:500S-6S.
3. Park SY, Park SW, Kang SK, Jun YH, Kim SK, Son BK, et al. Subclinical rickets in breastfed infants. Korean J Pediatr 2007;50:1188-93.

4. Ladhani S, Srinivasan L, Buchanan C, Allgrove J. Presentation of vitamin D deficiency. Arch Dis Child 2004;89:781-4.

5. Wagner CL, Greer FR; American Academy of Pediatrics Section on Breastfeeding; American Academy of Pediatrics Committee on Nutrition. Prevention of rickets and vitamin D deficiency in infants, children, and adolescents. Pediatrics 2008;122:114252.

6. Misra M, Pacaud D, Petryk A, Collett-Solberg PF, Kappy M; Drug and Therapeutics Committee of the Lawson Wilkins Pediatric Endocrine Society. Vitamin D deficiency in children and its management: review of current knowledge and recommendations. Pediatrics 2008;122:398-417.

7. Ward LM, Gaboury I, Ladhani M, Zlotkin S. Vitamin D-deficiency rickets among children in Canada. CMAJ 2007; 177:161-6.

8. Foo LH, Zhang Q, Zhu K, Ma G, Hu X, Greenfield H, et al. Low vitamin $\mathrm{D}$ status has an adverse influence on bone mass, bone turnover, and muscle strength in Chinese adolescent girls. J Nutr 2009;139:1002-7.

9. Strand MA, Perry J, Jin M, Tracer DP, Fischer PR, Zhang P, et al. Diagnosis of rickets and reassessment of prevalence among rural children in northern China. Pediatr Int 2007;49:202-9.

10. Fraser DR. Vitamin D-deficiency in Asia. J Steroid Biochem Mol Biol 2004;89-90:491-5.

11. Blok BH, Grant CC, McNeil AR, Reid IR. Characteristics of children with florid vitamin D deficient rickets in the Auckland region in 1998. N Z Med J 2000;113:374-6.

12. Shaw NJ, Pal BR. Vitamin D deficiency in UK Asian families: activating a new concern. Arch Dis Child 2002;86:147-9.

13. Lee HS, Lim BT, Lee HS, Hwang JS. Vitamin D Deficiency in Breastfed Infants. J Korean Soc Pediatr Endocrinol 2008;13:158-62.

14. Choi EH, Jung SH, Jun YH, Lee YJ, Park JY, You JS, et al. Iron Deficiency Anemia and Vitamin D Deficiency in Breastfed Infants. Korean J Pediatr Gastroenterol Nutr 2010;13:164-71.

15. Kliegman RM, Behrman RE, Jenson HB, Stanton BF. Nelson textbook of pediatrics. 18th ed. Philadelphia PA: W.B. Saunders; 2000.

16. Weisberg P, Scanlon KS, Li R, Cogswell ME. Nutritional rickets among children in the United States: review of cases reported between 1986 and 2003. Am J Clin Nutr 2004;80:1697S-705S.

17. Haddad JG. Vitamin D-solar rays, the Milky Way, or both? 
N Engl J Med 1992;326:1213-5.

18. Sampson HA, McCaskill CC. Food hypersensitivity and atopic dermatitis: evaluation of 113 patients. J Pediatr 1985;107:66975.

19. Norman AW, Bouillon R, Whiting SJ, Vieth R, Lips P. 13th Workshop consensus for vitamin D nutritional guidelines. J Steroid Biochem Mol Biol 2007;103:204-5.

20. Kimlin MG, Schallhorn KA. Estimations of the human 'vitamin D' UV exposure in the USA. Photochem Photobiol Sci 2004;3:1067-70.

21. Fox AT, Du Toit G, Lang A, Lack G. Food allergy as a risk factor for nutritional rickets. Pediatr Allergy Immunol 2004;15:566-9.

22. Seo JY, Kim C, Lee HW, Ahn YM. Eight cases of incidentally diagnosed as subclinical rickets. Korean J Pediatr 2008;51: 812-9.

23. Kim SK, Kim YK, Cho AJ, Kim HR, Lim SE. Current status of maternal and child health care. In: Kim SK editor. 2006 The survey on the national fertility, family health and welfare in Korea. Korea Institute for Health and Social Affairs, 2009;283.

24. Heinig MJ. Vitamin D and the breastfed infant: controversies and concerns. J Hum Lact 2003;19:247-9.

25. Gartner LM, Greer FR; Section on Breastfeeding and Committee on Nutrition. American Academy of Pediatrics. Prevention of rickets and vitamin D deficiency: new guidelines for vitamin D intake. Pediatrics 2003;111:908-10.

26. Turan S, Topcu B, Gökçe I, Güran T, Atay Z, Omar A, et al. Serum alkaline phosphatase levels in healthy children and evaluation of alkaline phosphatase z-scores in different types of rickets. J Clin Res Pediatr Endocrinol 2011;3:7-11.

27. Fleisher GA, Eickelberg ES, Elveback LR. Alkaline phosphatase activity in the plasma of children and adolescents. Clin Chem 1977;23:469-72. 